\title{
PERLINDUNGAN HUKUM TERHADAP PEMBELI ATAS TITIPAN BEA PEROLEHAN HAK ATAS TANAH DAN BANGUNAN KEPADA PEJABAT PEMBUAT AKTA TANAH
}

\author{
Muhammad Amaludin Riza \\ Magister Kenotariatan Universitas Narotama Surabaya \\ email : amaludin.riza2018@gmail.com \\ Habib Adjie \\ Magister Kenotariatan Universitas Narotama Surabaya \\ Email : adjieku61@gmail.com
}

\begin{abstract}
ABSTRAK
Pelaksanaan tugas jabatan Pejabat Pembuat Akta Tanah (PPAT) tidak lepas dari fungsinya untuk melayani masyarakat dengan sebaik mungkin. Atas dasar pelayanan terhadap masyarakat PPAT seringkali membantu pengurusan peralihan hak atas tanah bagi pembeli dengan menerima titipan pembayaran Bea Perolehan Hak Atas Tanah Dan Bangunan (BPHTB) untuk selanjutnya dibayarkan ke instansi terkait.

Penulis dalam penelitian ini ingin menelaah dan menganalisa lebih lanjut tentang kewenangan Pejabat Pembuat Akta Tanah (PPAT) dalam menerima titipan pembayaran Bea Perolehan Hak Atas Tanah Dan Bangunan (BPHTB) dan upaya hukum pembeli atas titipan BPHTB yang tidak dibayarkan oleh PPAT.

Metode penelitian yang digunakan adalah penelitian hukum normatif, yaitu penelitian hukum yang dilakukan dengan cara meneliti bahan pustaka atau bahan hukum sekunder sedangkan pendekatan masalah dilakukan dengan menggunakan pendekatan undang-undang dan pendekatan konseptual.

Hasil penelitian menunjukkan bahwa PPAT menerima titipan pembayaran BPHTB dari pembeli adalah dalam kapasitasnya sebagai pribadi berdasarkan kuasa dari penghadap, bukan dalam kedudukannya sebagai PPAT. Dalam konteks tersebut terdapat perikatan antara pribadi PPAT dengan pembeli sehingga terjadi suatu prestasi. Pembeli dapat melakukan gugatan atas dasar wanprestasi apabila BPHTB tidak dibayarkan oleh Pribadi PPAT.
\end{abstract}

Kata Kunci : Pejabat Pembuat Akta Tanah, Bea Perolehan Hak Atas Tanah Dan Bangunan, Titipan Pembayaran

\section{ABSTRACT}

Land deed officials (PPAT) have function to serve society in all situations and conditions. Commonly, land deed official is also helping the land buyer in paying all land taxes (BPHTB) to the tax department and other related departments. .

The present study tries to examine and elaborate further about the authority of land deed officials in helping to pay all land taxes (BPHTB). Moreover, the present study also tries to study legal protection of customer when all the land taxes (BPHTB) are not paid to the related departments by the land deed official (PPAT).

The method used in the present study is a normative legal research, namely legal research which is conducted by examining the library materials or secondary law while in finding and collecting the data is done by two approaches, namely the law and conceptual approaches. 
The present study shows that land deed official in helping customer to pay all land taxes (BPHTB) is included as their private capacity not as land deed official. In other words, there is some private connection between land deed officials as private individual and customer in form of business relation. Customer is able to sue land deed official as private individual when he/she does not paid all the land taxes (BPHTB) to the related departments.

Keywords: Land Deed Officials, Land Taxes, Buyer

\section{Pendahuluan}

Penyelenggaraan tugas negara tersebut memerlukan biaya yang identik dengan uang. Untuk mendapatkan uang, selain mencetak sendiri atau meminjam dari luar negeri, banyak jalan yang ditempuh oleh pemerintah (Darwin, 2010:1). sebagaimana tercantum dalam Anggaran Pendapatan dan Belanja Negara (APBN), pemasukan dana yang di terima oleh negara diperoleh dari Dalam Negeri, yang antara lain diperoleh dari Penerimaan Minyak, Gas, Pajak dan Bukan Pajak. Pajak telah menjadi primadona sebagai sektor yang memberikan penerimaan terbesar bagi negara serta merupakan salah satu sumber dana utama dalam melakukan pembangunan termasuk di negara Indonesia.

Menurut pendapat R. Santoso Brotohadiharjo, pajak adalah Iuran kepada negara (yang dapat dipaksakan), yang terutang oleh yang wajib membayarnya menurut peraturanperaturan dengan tidak mendapat prestasi kembali, yang langsung dapat ditunjuk, dan yang gunanya untuk membiayai pengeluaran-pengeluaran Umum berhubungan dengan tugas negara untuk menyelenggarakan pemerintahan (R. Santoso Brotodiharjo 2003:2).

Dasar hukum penerapan pemungutan pajak di Indonesia adalah ketentuan yang terdapat dalam Pasal 23 A Undang-Undang Dasar Negara Republik Indonesia 1945 yaitu dinyatakan bahwa semua pajak untuk keperluan negara berdasarkan undangundang. Besarnya peran yang diberikan oleh pajak sebagai sumber dana dalam pembangunan nasional, maka tentunya perlu lebih digali lagi potensi pajak yang ada dalam masyarakat sesuai dengan situasi dan kondisi perekonomian serta perkembangan bangsa ini. Salah satu sumber potensi pajak yang patut digali sesuai situasi dan kondisi perekonomian serta perkembangan pembangunan bangsa sekarang ini adalah jenis Pajak Bea Perolehan Hak Atas Tanah dan Bangunan

(BPHTB)(Marihot Pahalamana Siahaan, 2003:6).

Proses peralihan hak atas tanah dan atau bangunan hanya dapat dilakukan apabila wajib pajak telah menyerahkan bukti setor pembayaran pajak. Hal ini ditegaskan dalam Pasal 91 ayat (1) Undang-Undang Nomor 28 Tahun 2009 Tentang Pajak Dan Retribusi Daerah (UU PDRD) yang menyatakan : "Pejabat Pembuat Akta Tanah/Notaris hanya dapat menandatangani akta pemindahan Hak atas Tanah dan/atau Bangunan setelah Wajib Pajak menyerahkan bukti pembayaran pajak". Selanjutnya Pasal 91 ayat (1) Undangundang Nomor 28 Tahun 2009 tentang Pajak Daerah dan Retribusi Daerah menyebutkan : "Pejabat Pembuat Akta Tanah/Notaris dan kepala kantor yang membidangi pelayanan lelang negara, yang melanggar ketentuan sebagaimana dimaksud dalam Pasal 91 ayat (1) dan ayat (2) dikenakan sanksi administratif berupa denda sebesar Rp7.500.000,00 
(tujuh juta lima ratus ribu rupiah) untuk setiap pelanggaran".

Besarnya jumlah denda yang dikenakan kepada PPAT apabila melakukan pelanggaran terhadap ketentuan Pasal 91 ayat (1) UU PDRD, dirasa sangat memberatkan dan mengakibatkan PPAT dalam posisi yang sulit, karena kewajiban untuk membayar BPHTB itu sendiri sebenarnya adalah kewajiban dari wajib pajak yang memperoleh hak atas tanah dan atau bangunan. Hal ini yang menyebabkan PPAT terkadang membantu wajib pajak yang menjadi kliennya untuk menghitung pajak yang harus dibayar oleh wajib pajak, serta membantu untuk membayar dan melaporkan pajak BPHTB mereka.

Seorang Pejabat Umum seperti Pejabat Pembuat Akta Tanah (PPAT) dalam melakukan pekerjaannya sebagai pembuat akta otentik, tidak bisa lepas dari perpajakan yang secara langsung berhadapan dengan calon wajib pajak. Sehingga sudah sepantasnya Pejabat tersebut berperan serta untuk memberikan himbauan kepada calon wajib pajak tersebut untuk menyelesaikan kewajibannya membayar pajak, dalam prakteknya penghadap dalam hal ini para pihak penjual dan pembeli lebih merasa aman serta nyaman apabila uang pajak mereka titipkan kepada PPAT. Pembeli beranggapan bahwasanya PPAT adalah pihak yang berwenang untuk membayarkan pajak mereka, amanah yang di berikan oleh para pihak untuk menitipkan uang pembayaran pajak tidak diatur didalam Peraturan Pemerintah Nomor 37 Tahun 1998 Tentang Peraturan Jabatan Pejabat Pembuat Akta Tanah (PP PJPPAT), oleh karena itu titipan pembayaran Pajak BPHTB serta pajak PPH final pengalihan hak tidak sesuai dengan tugas dan wewenang sebagai PPAT.

\section{Rumusan Masalah}

1) Apa kewenangan PPAT untuk menerima uang titipan BPHTB transaksi jual beli?

2) Apa upaya hukum pembeli terhadap pajak BPHTB yang tidak dibayarkan oleh PPAT?

\section{Metode Penelitian}

Penelitian ini menggunakan metode penelitian hukum normatif yang dilakukan untuk mencari pemecahan masalah atas permasalahan hukum yang ada. Pendekatan penelitian yang digunakan adalah pendekatan undangundang (statute approach) dan pendekatan konseptual (conceptual approach).

\section{Pembahasan}

\section{Pemberian Kuasa Dari Pembeli Sebagai Dasar Pejabat Pembuat Akta Tanah Menerima Titipan Pembayaran Bea Perolehan Hak Atas Tanah Dan Bangunan}

Peralihan hak atas tanah dan bangunan berkaitan erat dengan kepastian hukum dan ditandai oleh adanya bukti atas peralihan hak tersebut. Untuk memberikan kekuatan dan kepastian hukum pemilikan tanah dan bangunan setiap peralihan hak atas tanah dan atau bangunan harus dilakukan sesuai dengan hukum yang mengaturnya. Perolehan hak sebagai hasil peralihan hak harus dilakukan secara tertulis dengan akta yang dibuat oleh pejabat yang berwenang, serta wajib didaftarkan pada instansi yang berwenang, yaitu kantor pertanahan Kabupaten/Kota setempat. Dengan demikian, hak atas tanah dan bangunan secara sah ada pada pihak yang memperoleh hak tersebut dan dapat 
dipertahankan terhadap semua pihak (Ibid:7).

Peralihan hak atas tanah dan bangunan menimbulkan adanya hak dan kewajiban bagi pihak yang mengalihkan maupun pihak yang menerima peralihan hak. Sebelum dilakukan jual beli ataupun peralihan hak atas tanah yang dilakukan dihadapan PPAT, maka penjual wajib terlebih dahulu membayar Pajak Penghasilan (PPh) dan pembeli wajib terlebih dahulu membayar Bea Perolehan Hak Atas Tanah dan Bangunan (BPHTB) ke Bank persepsi yang ditunjuk (Adimas Wahyu Widayat, 2016:166181). Pemerintah telah mengatur dalam peraturan perundang-undangan yang berlaku, dimana setiap orang pribadi atau badan yang memperoleh hak atas tanah dan bangunan wajib membayar pajak bea perolehan hak atas tanah dan bangunan yang dikenal dengan nama BPHTB.

Pasal 1 angka 41 UU PDRD menyatakan : "Bea Perolehan Hak atas Tanah dan Bangunan (BPHTB) adalah pajak atas perolehan hak atas tanah dan bangunan". Seperti yang disebutkan pada pengertian BPHTB itu sendiri, obyek pajak BPHTB adalah perolehan hak atas tanah dan atau bangunan. Pada pasal 86 Ayat (1) dan (2) UU PDRD disebutkan bahwa subjek pajak BPHTB adalah orang pribadi atau badan yang memperoleh hak atas tanah dan/atau bangunan serta yang menjadi wajib pajak BPHTB adalah orang pribadi atau badan yang memperoleh hak atas tanah dan/atau bangunan". Sistem pemungutan BPHTB adalah self assesment system, yaitu wajib pajak diberikan kepercayaan untuk menghitung sendiri serta membayar sendiri pajak yang terutang dengan mengggunakan surat setoran bea perolehan hak atas tanah dan bangunan dan melaporkannya tanpa mendasarkan kepada adanya surat ketetapan pajak (Witri, Mochammad Djudi, Sri Sulasmiyati, 2016:4).

Adanya ketentuan bahwa PPAT hanya dapat menandatangani akta pemindahan hak atas tanah dan/atau bangunan setelah wajib pajak menyerahkan bukti pembayaran pajak membuat PPAT dihadapkan pada situasi rumit bahwa secara tidak langsung PPAT diharuskan memastikan bahwa benar pajak-pajak yang berkaitan dengan peralihan tanah dan/atau bangunan tersebut telah dibayarkan. Kondisi tersebut melahirkan suatu "kebiasaan" dari pembeli dan PPAT untuk menitipkan pembayaran BPHTB kepada PPAT.

PPAT sebagaimana disebutkan dalam Pasal 1 angka 1 PP PJPPAT memiliki tugas pokok untuk melaksanakan sebagian kegiatan pendaftaran tanah dengan membuat akta sebagai bukti telah dilakukannnya perbuatan hukum tertentu mengenai hak atas tanah atau Hak Milik Atas Satuan Rumah Susun, yang akan dijadikan dasar bagi pendaftaran perubahan data pendaftaran tanah yang diakibatkan oleh perbuatan hukum. Perbuatan hukum yang dimaksud di atas adalah jual-beli, tukar-menukar, hibah, pemasukan ke dalam perusahaan (inbreng), pembagian hak bersama, pemberian hak guna bangunan/hak pakai atas tanah hak milik, pemberian hak tanggungan dan pemberian kuasa membebankan hak tanggungan (Hatta Isnaini Wahyu Utomo dan Hendry Dwicahyo Wanda, 2017:467487).

Dari tugas pokok dan kewenangan PPAT sebagaimana disebutkan diatas, terlihat bahwa tugas pokok dan kewenangan PPAT adalah untuk membuat 8 (delapan) macam akta yang berkaitan dengan perbuatan hukum dalam lingkup pertanahan. PP PJPPAT sama sekali tidak menyebutkan bahwa 
PPAT berwenang untuk menerima titipan pembayaran pajk maupun hal lainnya. Sehingga dalam hal ini dapat dipahami bahwa adanya titipan pembayaran pajak seperti halnya titipan pembayaran BPHBT bukan berdasarkan kewenangan PPAT sebagaimana disebutkan dalam PP PJPPAT tetapi lahir dari kebiasaan.

Kebiasaan merupakan sumber hukum yang ada di dalam kehidupan sosial masyarakat dan dipatuhi sebagai nilai-nilai hidup yang positif. Kebiasaan ialah perbuatan manusia mengenai hal tertentu yang tetap, dilakukan berulangulang dalam rangkaian perbuatan yang sama dalam waktu yang lama. Kebiasaan yang diyakini oleh masyarakat jelas akan diterima sebagai hukum yang harus ditaati. Namun tidak semua kebiasaan itu mengandung hukum yang adil dan mengatur tata kehidupan masyarakat, sehingga tidak semua kebiasaan itu dapat dijadikan sumber hukum. Kebiasaan (custom) dapat diartikan sebagai sumber hukum dalam arti formal yang tidak tertulis. Kebiasaan adalah perbuatan manusia yang tetap dilakukan berulang-ulang dalam hal yang sama. Apabila suatu kebiasaan tertentu diterima oleh masyarakat dan kebiasaan itu selalu berulang-ulang dilakukan sedemikan rupa, sehingga tindakan yang berlawanan dengan kebiasaan itu dirasakan sebagai pelanggaran peraturan hukum, maka dengan demikian timbullah suatu kebiasaan hukum, yang oleh pergaulan hidup dipandang sebagai hukum (Fence $\mathrm{M}$. Wantu, 2015:18).

PPAT pada hakikatnya adalah suatu jabatan. Menurut Habib Adjie, jabatan merupakan suatu bidang pekerjaan atau tugas yang sengaja dibuat oleh aturan hukum untuk keperluan dan fungsi tertentu serta bersifat berkesinambungan sebagai suatu lingkungan pekerjaan tetap. Jabatan merupakan suatu subyek hukum yakni pendukung hak dan kewajiban. Agar suatu jabatan dapat berjalan maka jabatan tersebut disandang oleh subyek hukum lainnya yaitu orang. Orang yang diangkat untuk melaksanakan jabatan disebut pejabat. Suatu jabatan tanpa ada pejabatnya, maka jabatan tersebut tidak dapat berjalan. Jabatan-jabatan tersebut diisi atau dijabat oleh para subyek hukum yang dipilih atau diangkat untuk waktu tertentu yang akan menjalankan jabatan yang ada (Habib Adjie, 2008:10-11).

Pendapat serupa dikemukakan oleh Logemann yang menghendaki suatu kepastian dan kontinuitas pada suatu jabatan supaya organisasi dalam berfungsi dengan baik. Jabatan dijalankan oleh pribadi sebagai wakil dalam kedudukan demikian dan berbuat atas nama jabatan, yang disebut pemangku jabatan. Jabatan muncul sebagai pribadi (persoon) atau subjek hukum, yang dibebani kewajiban dan dijadikan berwenang untuk melakukan perbuatan hukum, akan tetapi untuk melakukan tindakan harus melalui "pejabat" atau "pemangku jabatan" (Logemann, 1975:124).

Dari uraian mengenai jabatan sebagaimana telah disebutkan diatas dapat diperoleh unsur yang berkaitan dengan suatu jabatan yaitu : 1) jenis jabatannya dan 2) pejabatnya atau pemangku jabatannya. Pemangku jabatan merupakan subyek hukum yang dapat bertindak dengan dibebani hak dan kewajiban. Hal tersebut apabila dikaitkan dengan PPAT maka dalam diri PPAT terdapat jabatan dan pemangku jabatannya. Suatu jabatan bertindak berdasarkan kewenangan yang dimiliki sedangkan untuk pemangku jabatan sebagai subyek hukum dapat bertindak berdasarkan jabatannya maupun 
bertindak sebagai pribadi diluar jabatannya.

Kebiasaan pembeli untuk menitipkan pembayaran pajak BPHTB kepada PPAT dibingkai dalam bentuk pemberian kuasa. Kuasa dalam hal ini diberikan ke PPAT yang bertindak dalam kapasitasnya selaku pribadi dan bukan dalam jabatannya selaku PPAT. Atas dasar inilah PPAT dapat bertindak secara hukum untuk mewakili wajib pajak dalam membayarkan BPHTB dan dengan adanya kuasa inilah wajib pajak menitipkan pembayaran BHTB kepada PPAT.

\section{Pasal 1792 Burgerlijk Wetboek} (BW), memberikan rumusan tentang pemberian kuasa, yaitu : "Pemberian kuasa adalah suatu persetujuan dengan mana seorang memberikan kekuasaan kepada seorang lain, yang menerimanya, untuk atas namanya menyelenggarakan suatu urusan." Kata "persetujuan"menunjukkan pemberian kuasa menganut konsep sebagai perjanjian (lastgeving),di mana ketentuan syarat-syarat sahnya suatu perjanjian dan asas-asas hukum yang fundamental, yaitu asas konsensualisme, asas kebebasan berkontrak dan asas kekuatan mengikat, berlaku bagi perjanjian pemberian kuasa. Kata "untuk dan atas nama" ditafsirkan bahwa dalam perjanjian pemberian kuasa, selalu melahirkan perwakilan, yang membawa akibat bahwa ketentuan lastgeving berlaku bagi pemberian kuasa yang melahirkan perwakilan (volmacht) (Pieter E. Latumeten, 2017:3). Selanjutnya, rumusan dalam Pasal 1792 BW tentang "menyelenggarakan suatu urusan" dimaknai melakukan suatu perbuatan hukum, yaitu suatu perbuatan yang mempunyai atau melahirkan suatu akibat hukum. Dengan demikian pemberian kuasa tersebut dimaksudkan pemberian wewenang untuk melakukan suatu perbuatan hukum untuk kepentingan dan atas nama pemberi kuasa.

Pemberian kuasa tidak terikat terhadap formalitas tertentu baik cara pemberian kuasa maupun bentuknya, sebagaimana yang telah dirumuskan dalam Pasal 1793 BW, yaitu : "Kuasa dapat diberikan dan diterima dalam suatu akta umum, dalam suatu tulisan di bawah tangan, bahkan dalam sepucuk surat ataupun dengan lisan". Penerimaan suatu kuasa dapat pula terjadi secara diam-diam dan disimpulkan dari pelaksanaan kuasa itu oleh si kuasa". Pemberian kuasa tersebut merupakan pemberian kuasa yang bersifat umum, sehingga tidak memerlukan formalitas khusus, lain halnya dengan pemberian kuasa yang bersifat khusus seperti yang di atur pada Pasal 1795 BW bahwa pemberian kuasa dapat dilakukan secara khusus yaitu mengenai hanya satu kepentingan tertentu atau lebih, atau secara umum yaitu meliputi segala kepentingan si pemberi kuasa. Yang mana perbuatan ini hanya dapat dilakukan oleh seorang pemilik, diperlukan suatu pemberian kuasa dengan kata-kata yang tegas.

Seorang kuasa menerima kuasa dari pemberi kuasa hanya dalam hubungan intern antara pemberi kuasa dan penerima kuasa, dimana penerima kuasa tidak berhak mewakili pemberi kuasa untuk melakukan hubungan dengan pihak ketiga, maka perjanjian kuasa ini tidak melahirkan suatu perwakilan. Artinya bahwa pemberian kuasa merupakan suatu perjanjian yang melahirkan perwakilan, yaitu adanya orang yang mewakili orang lain untuk melakukan perbuatan hukum (Sudaryati, 2011:56).

Menurut Hatta Isnaini Wahyu Utomo, mengenai pemberian kuasa dapat dilakukan dengan akta otentik, 
dalam bentuk tulisan di bawah tangan, dan dengan lisan. Pemberian kuasa dengan akta otentik adalah suatu pemberian kuasa yang dibuat antara pemberi kuasa dan penerima kuasa, artinya perjanjian kuasa itu dibuat di muka dan di hadapan notaris. Pemberian kuasa dalam bentuk tulisan di bawah tangan merupakan perjanjian pemberian kuasa yang dibuat secara tertulis antara pemberi kuasa dan penerima kuasa, sedangkan perjanjian pemberian kuasa secara lisan merupakan perjanjian pemberian kuasa artinya pihak pemberi kuasa memberikan kuasa secara lisan kepada peneriman kuasa tentang hal yang dikuasakannya (Hatta Isnaini Wahyu Utomo, 2018:8).

Isi pemberian kuasa ditentukan oleh pihak pemberi kuasa. Pemberian kuasa bisaanya memberikan kuasa kepada penerima kuasa untuk mewakilinya, baik di luar pengadilan maupun di muka pengadilan. Mengenai isi pemberian kuasa dapat dibedakan menjadi 2 (dua) yaitu pemberian kuasa secara khusus dan pemberian kuasa secara umum, pemberian kuasa yang dirumuskan dalam kata-kata umum hanya meliputi perbuatan-perbuatan yang bersifat kepengurusan (beheren), sedangkan pemberian kuasa secara khusus yaitu untuk perbuatanperbuatan yang dimaksud menindahtangankan benda-benda, untuk meletakkan hipotik atau Hak Tanggungan, melakukan perdamaian dan lain sebagainya hanya dapat dilakukan oleh pemilik (Salim H.S, 2010:86).

Meskipun secara normatif dalam pelaksanaan jabatan PPAT tidak terdapat kewenangan maupun kewajiban bagi PPAT untuk menerima titipan pembayaran BPHTB tetapi berdasarkan kebiasaan yang dituangkan dalam konsep pemberian kuasa maka PPAT dalam kapasitasnya sebagai pribadi yang merupakan subyek hukum dapat menerima titipan pembayaran BPHTB dari pembeli.

\section{Upaya Hukum Pembeli Terhadap Titipan Pajak Bea Perolehan Hak Atas Tanah Dan Bangunan Yang Tidak Dibayarkan Oleh Pejabat Pembuat Akta Tanah}

Kewajiban pembayaran BPHTB pada prinsipnya adalah kewajiban dari Wajib Pajak dan bukan kewajiban dari PPAT. PPAT dalam hal ini hanya membantu kliennya untuk menyetorkan pajak BPHTB. PPAT hanya berusaha memberi pelayanan terbaik bagi kliennya atau dengan kata lain PPAT hanya menerima titipan pembayaran pajak pembelian atau BPHTB.

Adanya harapan untuk menerima pelayanan terbaik dari PPAT tidak selamanya berjalan sesuai harapan. Permasalahan yang sering terjadi berkaitan dengan titipan pembayaran BPHBT dari pembeli kepada PPAT adalah titipan tersebut tidak dibayarkan kepada yang berwenang yaitu kantor pajak. Dalam kondisi tersebut tentunya pembeli berhak untuk mendapatkan suatu bentuk perlindungan hukum atas titipan BPHTB yang tidak dibayarkan oleh PPAT. Disamping itu juga diperlukan suatu kejelasan mengenai upaya hukum yang dapat ditempuh oleh pembeli yang titipan BPHTBnya tidak dibayarkan oleh PPAT.

Adanya titipan pembayaran BPHTB yang diterima oleh PPAT melahirkan tanggungjawab bagi PPAT baik secara perdata maupun pidana. Mengenai bentuk pertanggungjawaban perdata bagi PPAT apabila titipan BPHTB tersebut tidak dibayarkan terlebih dahulu harus dilihat dari bentuk kuasa yang diterima PPAT untuk menentukan bahwa tidak dibayarkannya BPHTB oleh 
PPAT merupakan bentuk wanprestasi atau merupakan perbuatan melawan hukum.

Achmad Ichsan mengemukakan bahwa terdapat 3 (tiga) keadaan hukum berkaitan dengan hubungan hukum pemberian kuasa dan kewenangan mewakili, yaitu : (a) pemberian kuasa disertai kewenangan mewakili, yang melahirkan perwakilan berdasarkan perjanjian (lastgeving dan volmacht); (b) pemberian kuasa tanpa disertai kewenangan mewakili, tidak melahirkan perwakilan (lastgeving) dan (c) kewenangan mewakili tanpa pemberian kuasa (volmacht) (Achmad Ichsan, 1969:224). Essensi perbedaan antara lastgeving dan volmacht, yaitu volmacht memberikan kewenangan mewakili yang lahir dari tindakan hukum sepihak bukan kewajiban mewakili, sedangkan lastgeving memberikan kewajiban mewakili yang lahir dari perjanjian, jika ada kewenangan mewakili dalam lastgeving tersebut atau kewajiban bertindak (melaksanakan prestasi), jika tidak ada kewenangan mewakili dalam lastgeving (Peter Latumeten, Op. Cit:8).

Ciri atau karakteristik volmacht, yaitu : (a) volmacht bukan termasuk dalam perjanjian obligatoir dan tidak melahirkan perikatan (hak dan kewajiban) antara pemberi kuasa dan penerima kuasa); (b) volmacht tidak memiliki daya kerja privative, artinya kuasa dapat dicabut kembali secara sepihak atau pemberi kuasa dapat melakukan tindakan hukum sendiri meskipun telah memberikan kuasa kepada orang lain; (c) volmacht tidak memerlukan adanya tindakan penerimaan kuasa oleh penerima kuasa, karena volmachtbukan suatu perjanjian; (d) volmacht sebagai tindakan hukum sepihak, tidak berlaku ketentuan Buku III tentang Perikatan, KUHPerdata; dan (e) volmacht sebagai tindakan hukum sepihak, jika penerima kuasa menggunakan kuasanya, maka lahir hubungan hukum antara pemberi kuasa dengan pihak ketiga, dan tidak melahirkan hubungan hukum antara pemberi kuasa dan penerima kuasa; (f) dalam hal penerima kuasa melakukan suatu tindakan hukum yang melampaui kewenangan yang diberikan dalam kuasa atau penerima kuasa melakukan perbuatan melawan hukum dalam penggunaan kuasa, maka penerima kuasa bertanggung jawab kepada pihak ketiga (Herlien Budiono, 2008:269-270).

Sedangkan karakteristik dari pengertian lastgeving sebagai perjanjian pemberian perintah dapat dijabarkan sebagai berikut : (a) lastgeving merupakan perjanjian sepihak, yang meletakkan kewajiban untuk melaksanakan prestasi pada salah satu pihak (lasthebber) dan bukan kewajiban atau kewenangan mewakili; (b) penerima perintah (lasthebber) bertindak atas nama lasthebber sendiri dan tidak boleh bertindak sebagai wakil dari pemberi perintah (lastgever); (c) penerima perintah (lasthebber)bertindak atas nama lastgever,jika ada kewenangan mewakili dari lastgever; (d) jika penerima perintah (lasthebber) tidak melaksanakan perintah dari lastgever, maka lastheber telah melakukan wanprestasi terhadap lastgever (Ibid).

Untuk mengkonstruksikan hubungan yang terdapat antara pembeli dengan PPAT maka terlebih dahulu melihat ketentuan dalam Pasal 1794 BW yang menyatakan : "Pemberian kuasa terjadi dengan cuma-cuma, kecuali jika diperjanjikan sebaliknya. Jika dalam hal yang terakhir upahnya tidak ditentukan dengan tegas, maka penerima kuasa tidak boleh meminta upah yang lebih daripada yang ditentukan dalam Pasal 411 untuk wali". Faktor upah menjadi 
penentu dari hubungan hukum yang ada antara pembeli yang menitipkan BPHTB dan PPAT. Apabila tidak terdapat upah maka hubungan hukum yang ada hanya merupakan perjanjian sepihak yang menempatkan kewajiban untuk melaksanakan prestasi pada penerima kuasa saja. Namun sebaliknya jika diperjanjikan upah maka hubungan hukum tersebut menjadi timbal balik dan kewajiban untuk pemenuhan prestasi ada pada kedua belah pihak.

$$
\text { Pada saat dalam titipan }
$$

pembayaran BPHTB tidak diperjanjikan upah maka apabila titipan BPHTB tersebut tidak dibayarkan oleh PPAT maka PPAT melakukan perbuatan melawan hukum. Menurut Munir Fuady, perbuatan melawan hukum dalam arti yang luas yaitu perbuatan-perbuatan yang mencakup dari salah satu perbuatan antara lain :

Perbuatan yang bertentangan dengan hak orang lain; 2) Perbuatan yang bertentangan dengan kewajiban hukumnya sendiri, baik itu hukum tertulis maupun hukum tidak tertulis; 3 ) Perbuatan yang bertentangan dengan kesusilaan, manakala perbuatan tersebut mengakibatkan kerugian orang lain; 4) Perbuatan yang bertentangan dengan prinsip kehati-hatian atau keharusan dalam pergaulan masyarakat yang baik, yang diakui oleh masyarakat (Munir Fuady, 2010:48). Atas dasar tersebut pembeli yang titipan BPHTBnya tidak dibayarkan oleh PPAT dapat melakukan gugatan atas dasar perbuatan melawan hukum yang dilakukan oleh PPAT.

Apabila dalam titipan pembayaran BPHTB diperjanjikan upah maka, pada saat PPAT tidak membayarkan titipan BPHTB tersebut PPAT telah melakukan wanprestasi. Wanprestasi merupakan kelalaian untuk memenuhi kewajibannya sesuai dengan perjanjian yang telah disepakati (Akhmad Budi Cahyono dan
Surini Ahlan Sjarif, 2010:141). Untuk menentukan kapan seseorang telah melalaikan kewajibannya dapat dilihat dari isi perjanjian. Dalam perjanjian biasanya diatur kapan seseorang harus melaksanakan kewajibannya, seperti menyerahkan sesuatu barang atau melakukan suatu perbuatan. Apabila dalam perjanjian tidak disebutkan kapan seseorang harus menyerahkan sesuatu atau berbuat sesuatu, maka sebelum mengajukan gugatan wanprestasi seorang kreditur harus memberikan somasi atau surat peringatan yang menyatakan bahwa kreditur telah lalai dan agar memenuhi kewajibannya dalam jangka waktu tertentu. Apabila prestasi yang diperjanjikan adalah untuk tidak melakukan suatu perbuatan, maka tidak diperlukan somasi. Hal ini karena begitu debitur melakukan perbuatan yang dilarang, maka dia telah melakukan wanprestasi (Ibid).

Menurut Subekti, wanprestasi (kelalaian atau kealpaan) seorang debitur dapat berupa empat macam : a) tidak melakukan apa yang disanggupi akan dilakukannya; b) melaksanakan apa yang dijanjikannya tetapi tidak sebagaimana yang dijanjikannya; c) melaksanakan apa yang dijanjikannya, tetapi terlambat; dan d) melakukan sesuatu perbuatan, yang menurut perjanjian tidak boleh dilakukan (Subekti, 1998:45). Sehubungan dengan hal tersebut, ganti kerugian yang dapat dituntut atas dasar wanprestasi berupa : a) biaya, yaitu kerugian berupa biayabiaya yang telah dikeluarkan; b) rugi, yaitu kerugian yang sungguh-sungguh menimpa harta bendanya; c) bunga, yaitu keuntungan yang akan diperolehnya seandainya pihak debitur lalai (Ibid). Apabila telah diperjanjikan upah pada saat pembeli melakukan titipan pembayaran BPHTB kepada PPAT maka pembeli yang titipan BPHTBnya tidak 
dibayarkan oleh PPAT dapat melakukan gugatan atas dasar wanprestasi yang dilakukan oleh PPAT.

Selain adanya pertanggungjawaban secara perdata, berkaitan dengan tidak dibayarkannya titipan BPHTB oleh PPAT dapat menyeret PPAT ke ranah pidana. Seorang PPAT yang menyalahgunakan kepercayaan yang diberikan oleh klien dalam hal melakukan pembayaran BPHTB adalah merupakan suatu perbuatan pidana yang dapat diancam hukuman pidana penggelapan sesuai ketentuan Pasal 372 KUHP yang menyatakan : "Barang siapa dengan sengaja dan melawan hukum memiliki suatu benda yang seluruhnya atau sebagian milik orang lain, yang ada dalam kekuasaannya bukan karena kejahatan, diancam karena penggelapan dengan pidana penjara paling lama 4 (empat) tahun atau denda paling banyak Rp.900,-“

Dari rumusan Pasal 372 KUHP tersebut diatas dapat diperoleh norma bahwa penggelapan harus memenuhi unsur-unsur pokok berupa : 1) Unsur Subyektif Delik, yaitu berupa kesengajaan pelaku untuk menggelapkan barang milik orang lain yang dirumuskan dalam pasal undang-undang melalui kata : "dengan sengaja"; dan 2) Unsur Oyektif Delik yang terdiri atas : a) Unsur barang siapa; b) Unsur menguasai secara melawan hukum; c) Unsur suatu benda; d) Unsur sebagian atau seluruhnya milik orang lain; dan e) Unsur benda tersebut ada padanya bukan karena kejahatan. Jadi untuk dapat menyatakan seseorang sebagai pelaku penggelapan harus terlebih dahulu dibuktikan secara sah dan meyakinkan, apakah benar pada diri dan perbuatan orang tersebut telah terbukti unsur-unsur tindak pidana penggelapan baik berupa unsur subyektif maupun unsur obyektifnya.

\section{Kesimpulan}

PPAT yang menerima titipan pembayaran BPHTB dari pembeli bertindak dalam kapasitasnya selaku pribadi yang merupakan subyek hukum yang dapat dibebani hak dan kewajiban, bukan dalam jabatannya selaku PPAT. Titipan pembayaran BPHTB dari pembeli kepada PPAT dilaksanakan melalui pemberian Kuasa. Atas dasar pemberian kuasa dari pembeli tersebut PPAT dapat bertindak secara hukum untuk mewakili wajib pajak dalam membayarkan BPHTB.

Upaya hukum yang dapat dilakukan oleh pembeli yang titipan BPHTBnya tidak dibayarkan oleh PPAT dapat melalui gugatan perdata dan tuntutan pidana. Gugatan perdata yang dilakukan oleh pembeli terlebih dahulu melihat konstruksi hubungan hukum yang terjadi dengan PPAT. Apabila tidak diperjanjikan upah kepada PPAT pada saat menitipkan pembayaran BPHTB maka dapat dilakukan gugatan atas dasar perbuatan melawan hukum, tetapi apabila sebelumnya diperjanjikan adanya upah maka dapat dilakukan gugatan atas dasar wanprestasi. Selain dapat ditempuh gugatan perdata pembeli yang titipan BPHTBnya tidak dibayarkan dapat melakukan tuntutan pidana atas dasar penggelapan.

\section{Saran}

Diperlukan adanya suatu regulasi yang dengan tegas mengatur bentuk hubungan hukum antara PPAT dengan para pihak yang menitipkan pembayaran pajak kepada PPAT sehingga dapat tercapai adanya kepastian hukum .

PPAT dalam menerima titipan pembayaran diharapkan mampu menjalankan pekerjaannya dengan amanah sehingg tidak terjadi gugatan baik perdata maupun pidana kepada PPAT yang bersangkutan. 


\section{Daftar Pustaka}

Buku-Buku

Achmad Ichsan, Hukum Perdata , Pembimbing Masa, Jakarta, 1969

Akhmad Budi Cahyono dan Surini Ahlan Sjarif, Mengenal Hukum Perdata, Raja Grafindo, Jakarta, 2010

Darwin, Pajak Daerah Dan Retribusi Daerah, Mitra Wacana Media, Jakarta, 2010

Fence M. Wantu, Pengantar Ilmu Hukum, Reviva Cendekia, Gorontalo, 2015

Habib Adjie, Hukum Notaris Indonesia : Tafsir Tematik Terhadap UU No. 30 Tahun 2004 Tentang Jabatan Notaris, Refika Aditama, Bandung, 2008

Herlien Budiono, Kumpulan Tulisan Hukum Perdata Di Bidang Kenotariatan, Citra Aditya Bakti, Bandung, 2008

Logemann, Tentang Teori Suatu Hukum Tata Negara Positif, Ikhtiar BaruVan Hoeve, Jakarta, 1975

Marihot Pahalamana Siahaan, Bea Perolehan Hak Atas Tanah Dan Bangunan Teori Dan Praktek, Rajagrafindo Persada, Jakarta, 2003

Munir Fuady, Perbuatan Melawan Hukum : Pendekatan Kontemporer, Citra Adhitya Bakti, Bandung, 2010

R. Santoso Brotodiharjo, Pengantar Ilmu Hukum Pajak, Refika Aditama, Bandung, 2003

Salim H.S., Hukum Kontrak Teori Dan Teknik Penyusunan Kontrak, Sinar Grafika, Jakarta, 2010

Subekti, Hukum perjanjian, Intermasa, Jakarta, 1998

\section{Jurnal Dan Makalah}

Adimas Wahyu Widayat, "Analisis Pengenaan Bea Perolehan Hak Atas Tanah Dan Bangunan Dalam Proses Jual Beli Tanah Dan Bangunan Di
Kabupaten Kebumen", Jurnal Lex Renaissance, No. 2 Vol. 1 Juli 2016

Hatta Isnaini Wahyu Utomo Dan Hendry Dwicahyo Wanda, "Prinsip KehatiHatian Pejabat Pembuat Akta Tanah Dalam Peralihan Tanah Yang Belum Bersertifikat, Jurnal Ius Quia Iustum, No. 3 Vol. 24 Juli 2017

-----, “Pelaksanaan Tugas Jabatan Notaris : Bahan Diskusi Dalam Persiapan Menghadapi Ujian Kode Etik Notaris", Makalah, disampaikan pada acara Belajar Bareng Alumni, Universitas Narotama Surabaya, Februari 2018

Pieter E. Latumeten, "Reposisi Pemberian Kuasa Dalam Konsep Volmacht Dan Lastgeving Berdasarkan Cita Hukum Pancasila", Jurnal Hukum Dan Pembangunan, Tahun Ke-47 No.1, Januari-Maret 2017

Sudaryati, "Prinsip-Prinsip Hukum Surat Kuasa Membebankan Hak Tanggungan (SKMHT) Pada Perjanjian Kredit Pemilikan Rumah", Tesis, Fakultas Hukum Universitas Jember, 2011

Witri, Mochammad Djudi, Sri Sulasmiyati, "Analisis Pelimpahan Bea Perolehan Hak Atas Tanah Dan Bangunan (BPHTB) Kepada Pemerintah Daerah Terhadap Pendapatan Asli Daerah (PAD)", Jurnal Perpajakan (Jejak), Vol. 9 No. 12016 